\title{
Effects of different concentrations of sodium azide and chloramphenicol on the preservation of raw milk samples
}

\author{
Franciele Rampazzo Vancin ${ }^{1,2^{*}}$ (D) Bruna Webber $^{1}$ (D) Carlos Bondan ${ }^{1}$ (D) Luciane Daroit ${ }^{1}$ (D) \\ Luciana Ruschel dos Santos ${ }^{1}$ (D) Laura Beatriz Rodrigues ${ }^{1}$ iD
}

${ }^{1}$ Programa de Pós-graduação em Ciência e Tecnologia de Alimentos, Universidade de Passo Fundo (UPF), Passo Fundo, RS, Brasil. ${ }^{2}$ Laboratório Estadual da Qualidade de Leite, Universidade do Contestado (UnC), 89700-202, Concórdia, SC, Brasil. E-mail: franrvancin@yahoo.com.br. ${ }^{*}$ Corresponding author.

ABSTRACT: The preservation of milk samples for microbiological analyses by the Brazilian Network of Milk Quality Control Laboratories requires the addition of preservatives to maintain the microbiota from the time of sample collection to the moment of analysis. The number of microorganisms can change as a result of the active ingredients and concentration of the preservative, as well as due to interactions between the preservatives, incubation time, and packaging temperature. The objective of this research was to evaluate the conservation potential of different concentrations of sodium azide and chloramphenicol on the analytical shelf life of milk samples. Two farms were selected, one with a low bacterial count and one with a high bacterial count. The milk was dispensed into sterile vials and tested after the addition of the usual concentrations of sodium azide and chloramphenicol, doubled concentrations, tripled concentrations, and as a control, without preservatives. The samples were incubated at $3 \pm 1{ }^{\circ} \mathrm{C}, 6 \pm 1{ }^{\circ} \mathrm{C}$, and $9 \pm 1{ }^{\circ} \mathrm{C}$ for 14 days and analyzed daily for their bacterial count by flow cytometry. The tripled preservative concentrations improved conservation, increasing the timespan of the analytical viability of the samples without altering the results.

Key words: milk, azidiol, individual bacterial count, flow cytometry.

Efeitos de diferentes concentrações de azida sódica e cloranfenicol na preservação de amostras de leite cru

RESUMO: A conservação das amostras de leite destinadas para análises microbiológicas pela Rede Brasileira de Laboratórios de Controle da Qualidade do Leite requer adição de conservantes para a preservação da microbiota existente desde o momento da coleta até as análises. $O$ número de microrganismos pode apresentar alterações decorrentes do princípio ativo e concentração do conservante, e ainda entre as interações conservante, tempo de incubação e temperatura de acondicionamento. O objetivo deste trabalho foi avaliar o potencial de conservação de diferentes concentrações de azida sódica e cloranfenicol sobre a vida útil analítica de amostras de leite. Foram selecionadas duas fazendas, sendo uma com baixa contagem bacteriana e outra com alta contagem bacteriana. O leite foi fracionado em frascos estéreis e testado nas seguintes condições: pastilhas com a concentração usual de azida sódica e cloranfenicol, com dupla concentração, com tripla concentração e sem a adição do conservante. As amostras foram incubadas por quatorze dias a $3 \pm 1{ }^{\circ} \mathrm{C}, 6 \pm 1{ }^{\circ} \mathrm{C}$ e $9 \pm 1{ }^{\circ} \mathrm{C}$, e analisadas diariamente por citometria de fluxo para a determinação da contagem bacteriana. A tripla concentração do conservante demonstrou maior conservação, possibilitando o aumento da viabilidade analítica das amostras sem alteração nos resultados.

Palavras-chave: leite, azidiol, contagem bacteriana individual, citometria de fluxo.

\section{INTRODUCTION}

Following the Normative Instructions by the Brazilian Ministry of Agriculture, Livestock, and Food Supply, milk samples destined for processing at federally inspected establishments must undergo monthly analyses at accredited laboratories (BRASIL, 2002) that are a part of the Brazilian Network of Milk Quality Control Laboratories. The parameters analyzed included the bacterial count, which is typically done by flow cytometry.
The bacterial count reflects the hygiene of the storage conditions during sample collection and the period between milking and milk collection on the farm. Poor hygiene can contaminate the samples or predispose them to microbial proliferation. Milk can be contaminated by microorganisms in the environment, which could be failures in the milking, water, or udder management (SAMPAIO et al., 2015). One main source of contamination is a failure in the milk cooling process during tank storage, which can also impair the microbiological quality 
of the raw material (TRONCO, 2010). Chilled raw milk is permitted to have a quarterly bacterial count geometric mean of up to 300,000 colony forming units (CFU)/mL (BRASIL, 2018), equivalent to an $\sim 824,000$ individual bacteria count (IBC)/mL.

One challenge in the milk production chain is the preservation of samples, keeping them representative of their collection at the time of their analysis. Under tropical and subtropical climate conditions, and especially with longer times between collection and analysis, this requires the addition of a bacteriostatic preservative that negatively interferes with the maintenance of the microbial population (CASSOLI et al., 2010; WENTZ et al., 2018).

In some countries, cooling alone is sufficient to preserve samples without the need for preservatives. However, in these cases, the distances between farms and laboratories is usually short, allowing for an analysis within 48 hours of collection. Given the territorial extent and number of producers in Brazil, performing analyses within 48 hours is virtually impossible (CASSOLI et al., 2010). Between the warm climate in Brazil and the distances between the farms and laboratories that result in excessively long times between collection and analysis, the use of preservatives is a necessity. At present, preservative use is assumed to guarantee the analytical viability of samples that are kept refrigerated at a maximum temperature of $10{ }^{\circ} \mathrm{C}$ for up to seven days. When the period between collection and analysis exceeds seven days, the dairy plants must make new collections, which results in higher costs and operational difficulties (ALMEIDA et al., 2016).

The bacteriostatic preservative currently permitted to be added to milk samples is azidiol, which is composed of sodium azide and chloramphenicol. These act by inhibiting protein synthesis, thus prolonging the milk preservation time. The use of a preservative with higher concentrations of sodium azide and chloramphenicol than are currently used may be an alternative for preserving the samples for a longer period. Given the shortage of information on changes in the bacterial counts in raw milk samples at different preservative concentrations, this study was intended to evaluate three concentrations of sodium azide and chloramphenicol over different incubation times at three different temperatures.

\section{MATERIALS AND METHODS}

\section{Sample collection and preparation}

Samples were prepared with in natura bovine milk collected from cooling tanks on two farms in Concórdia (Santa Catarina, Brazil). Samples had previously known bacterial counts, with Group 1 (G-1) having a bacterial count in accordance with current regulations $(<50,000 \mathrm{CFU} / \mathrm{mL}$ or $\sim 145,000$ $\mathrm{IBC} / \mathrm{mL}$ ), while the bacterial count for Group 2 (G-2) was above the current regulations $(>1,000,000 \mathrm{CFU} /$ $\mathrm{mL}$ or $\sim 2,650,000 \mathrm{IBC} / \mathrm{mL}$ ).

The temperature of milk in cooling tanks did not exceed $4{ }^{\circ} \mathrm{C}$ at the time of collection. The agitator was turned on for 10 minutes prior to collection and maintained during the collection. The milk from each farm was transferred to a previously sterilized labeled container, packed in isothermal boxes with reusable ice immediately after collection, and sent to the lab.

Working in a laminar flow cabinet in the lab, $40 \mathrm{~mL}$ of milk from groups G-1 and G-2 were dispensed into 720 sterile $50-\mathrm{ml}$ capacity polypropylene bottles with and without different amounts of added azidiol (i.e., with different concentrations of sodium azide and chloramphenicol). Contents in the bottles were homogenized with smooth and uninterrupted inversion motions.

The four treatment groups were as follows: $\mathrm{T}-1$, the usual concentration of sodium azide and chloramphenicol, tablets equivalent to $4.79 \mathrm{mg}(0.12$ $\mathrm{mg} / \mathrm{mL})$ of sodium azide and $0.2 \mathrm{mg}(0.005 \mathrm{mg} /$ $\mathrm{mL}$ ) of chloramphenicol; T-2, double the normal concentration of sodium azide and chloramphenicol, equivalent to $9.58 \mathrm{mg}(0.24 \mathrm{mg} / \mathrm{mL})$ of sodium azide and $0.4 \mathrm{mg}(0.010 \mathrm{mg} / \mathrm{mL})$ of chloramphenicol; T-3, triple the normal concentration of sodium azide and chloramphenicol, equivalent to $14.37 \mathrm{mg}(0.36 \mathrm{mg} /$ $\mathrm{mL})$ of sodium azide and $0.6 \mathrm{mg}(0.015 \mathrm{mg} / \mathrm{mL})$ of chloramphenicol; and T-4, no preservatives added, which served as the control sample. Samples were incubated at $3 \pm 1{ }^{\circ} \mathrm{C}, 6 \pm 1{ }^{\circ} \mathrm{C}$, and $9 \pm 1{ }^{\circ} \mathrm{C}$ for 14 days with a daily analysis of the bacterial count using a flow cytometer. Treatments applied to the G-1 and G-2 milk samples and their respective sodium azide and chloramphenicol concentrations, incubation time, and storage temperatures are shown in table 1.

\section{Testing}

The bacteria were counted using Bentley BactoCount $\mathrm{IBC}^{\circledR} \quad 150 \quad$ (Bentley Instruments Incorporated, Chaska, USA) equipment, which uses flow cytometry, according to the ISO 21187/IDF 196 standards - Milk: Quantitative determination of bacteriological quality - Guidance for establishing and verifying a conversion relationship between routine method results and anchor method results. Results were reported as individual bacterial counts 
Table 1 - Concentrations of the sodium azide and chloramphenicol (azidiol) preservatives and the incubation time and temperatures for the G-1 and G-2 milk samples.

\begin{tabular}{|c|c|c|c|c|}
\hline & \multicolumn{2}{|c|}{ 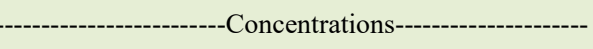 } & \multirow[t]{2}{*}{ Incubation Time (days) } & \multirow[t]{2}{*}{ IncubationTemperature $\left({ }^{\circ} \mathrm{C}\right)$} \\
\hline & Sodium Azide (mg) & Chloramphenicol (mg) & & \\
\hline $\mathrm{T}-1$ & 4.79 & 0.2 & 14 & $3 \pm 1 ; 6 \pm 1 ; 9 \pm 1$ \\
\hline $\mathrm{T}-2$ & 9.58 & 0.4 & 14 & $3 \pm 1 ; 6 \pm 1 ; 9 \pm 1$ \\
\hline $\mathrm{T}-3$ & 14.37 & 0.6 & 14 & $3 \pm 1 ; 6 \pm 1 ; 9 \pm 1$ \\
\hline $\mathrm{T}-4^{*}$ & - & - & 14 & $3 \pm 1 ; 6 \pm 1 ; 9 \pm 1$ \\
\hline
\end{tabular}

*Control, no preservatives.

Abbreviations:

G-1, milk samples with a bacterial count within current regulations; G-2, milk samples with a bacterial count exceeding current regulations; T-1: usual azidiol dosage; T-2, double azidiol dosage; T-3, triple azidiol dosage; T-4, no preservatives.

(IBC/mL). All conditions were tested in quadruplicate, with each sample analyzed individually in the flow cytometer with three measurements per bottle.

\section{Statistical analysis}

The bacterial count results were transformed to base-10 logarithms and subjected to an analysis of variance that considered the effects of the times, temperatures, and treatments as well as their interactions. A Tukey test was applied to the temperatures and treatments. The action of time on the samples was analyzed using the times at zero (Day 0) and one (Day 1) for comparison with the subsequent times. A linear correlation (Pearson) was used to evaluate the different incubation times.

\section{RESULTS AND DISCUSSION}

For Group 1, with a bacterial count according with current regulations, comparing the results from the date of collection (Day 0 ) with the other days within the same treatment and temperature revealed differences $(\mathrm{P}<0.05)$ in the means for the treatments with preservative added on Day 1 . We also observed differences $(\mathrm{P}<0.05)$ in the means within all treatments at all incubation temperatures for Group 2, in which the bacterial counts exceeded current regulations.

Evaluating the analytic viability of the samples in G-1, we obtained similar results for T-1 (usual concentration) and T-2 (doubled concentration) at the three incubation temperatures, with both treatments showing very similar results $(\mathrm{P}>0.05)$ throughout the experiment. At $3{ }^{\circ} \mathrm{C}$, the T-1 samples did not differ $(\mathrm{P}>0.05)$ until Day $6(4.88 \pm 0.05)$, while those for $\mathrm{T}-2$ did not statistically differ $(\mathrm{P}>0.05)$ until after Day $4(4.88 \pm 0.06)$. The samples from the two treatments incubated at $6{ }^{\circ} \mathrm{C}$ and $9{ }^{\circ} \mathrm{C}$ did not significantly differ until after Day $4\left(6{ }^{\circ} \mathrm{C}\right.$ : T-1, 4.80 \pm 0.07 and T-2, $4.82 \pm 0.03, \mathrm{P}>0.05 ; 9{ }^{\circ} \mathrm{C}: \mathrm{T}-1,4.91$ \pm 0.09 and $\mathrm{T}-2,4.82 \pm 0.06, \mathrm{P}>0.05)$. Thus, while it can be stated that the raw milk samples in Group 1 could be analyzed between the 4th and 6th days at 3 ${ }^{\circ} \mathrm{C}$ for treatments T- 1 and T-2 without a change in the results, the analytical viability decreased on the 4 th day for both treatments at $6{ }^{\circ} \mathrm{C}$ and $9{ }^{\circ} \mathrm{C}$.

Better preservation of the samples was observed in Group G-1 with the T-3 treatment (triple the normal concentrations of sodium azide and chloramphenicol), enabling an accurate analysis up to Day 12 when incubated at $3{ }^{\circ} \mathrm{C}(4.88 \pm 0.04)$ with no statistically significant change $(\mathrm{P}>0.05)$ and until Day 8 at $6{ }^{\circ} \mathrm{C}(4.96 \pm 0.04)$. The T-3 samples incubated at $9{ }^{\circ} \mathrm{C}$ only remained unchanged $(\mathrm{P}>0.05)$ until Day $4(4.83 \pm 0.07)$. This emphasizes the importance of keeping the samples at a low temperature, even with the use of a triple concentration of preservative, to enable a longer shelf life for the samples and prevent deterioration caused by microbial activity.

The tripled dosage of preservative may have favored the G-1 raw milk, which began with a low bacterial count $(<50,000 \mathrm{CFU} / \mathrm{mL}$, $\sim 145,000 \mathrm{IBC} / \mathrm{mL}$ ). However, we believed that due to the amount of bacteriostatic and antimicrobial components at this dosage, the bactericidal effect of the preservative needs to be further investigated using flow cytometry and markers to differentiate and quantify the viable vs. non-viable microorganisms in the sample. The tripled dosage of preservative appears to be a good alternative for use in the milk supply chain, because despite the higher costs relative to the usual preservative concentration, it increased the analytical longevity of samples. 
Regarding T-4 (no preservative added), it was not possible to preserve the G-1 samples, as low temperatures were insufficient in preventing an increase in the bacterial count, which quickly led to sample deterioration. Samples incubated at $3{ }^{\circ} \mathrm{C}$ remained viable until Day $3(4.97 \pm 0.17)$, but the analytical viability decreased by Day 2 at $6{ }^{\circ} \mathrm{C}(4.91$ $\pm 0.07)$, which was similar $(\mathrm{P}>0.05)$ to that on Day 1 (24 h) at $9{ }^{\circ} \mathrm{C}(5.10 \pm 0.04)$.

For the G-2 sample with $>1,000,000$ $\mathrm{CFU} / \mathrm{mL}(2,650,000 \mathrm{IBC} / \mathrm{mL})$, the longevity of the samples decreased considerably, with temperature as the determining factor. The T-1, T-2, and T-3 samples incubated at $3{ }^{\circ} \mathrm{C}$ remained viable to between Days 4 and 5 , with values of $6.48 \pm 0.01$ on Day 5 for T-1, and $6.46 \pm 0.01$ and $6.43 \pm 0.01$ on Day 4 for T-2 and $\mathrm{T}-3$, respectively. The samples incubated at $6{ }^{\circ} \mathrm{C}$ and $9^{\circ} \mathrm{C}$ had reduced viability on Day 3 (T-1: $6.50 \pm 0.01$; T-2: $6.46 \pm 0.01$; and T-3: $6.45 \pm 0.02$ ) and Day 2 (T1: $6.51 \pm 0.01 ; \mathrm{T}-2: 6.46 \pm 0.02$; and T-3: $6.45 \pm 0.04)$, respectively, with no significant differences $(\mathrm{P}>0.05)$ in the results.

The G-2 samples were preserved for an even shorter period when left untreated (T-4), which can be attributed to their high initial bacterial count. Samples significantly differed $(\mathrm{P}<0.05)$ within the first 24 hours of incubation at all temperatures tested $\left(3{ }^{\circ} \mathrm{C}, 7.06 \pm 0.02 ; 6{ }^{\circ} \mathrm{C}, 7.27 \pm 0.02\right.$; and $9{ }^{\circ} \mathrm{C}, 7.32$ \pm 0.03 ). As the counts increased, the measurements exceeded the analytical limits determined by the manufacturer $\left(9.9 \times 10^{6} \mathrm{CFU} / \mathrm{mL}\right)$. The deterioration of the samples was evidenced by the formation of clots, gas, and a foul odor, making it impossible to perform an analysis during the incubation period.

Comparing treatments (same incubation times and temperatures), the average values for the Group 1 samples incubated at $3{ }^{\circ} \mathrm{C}$ showed the largest variation $(\mathrm{P}<0.05)$, while the batch incubated at $6{ }^{\circ} \mathrm{C}$ only showed a significant difference $(\mathrm{P}<0.05)$ on Day 2. The samples incubated at $9{ }^{\circ} \mathrm{C}$ significantly differed on Day 4. The normal (T-1) and tripled (T-3) dosages also statistically differed $(\mathrm{P}<0.05)$.

In Group 2, samples incubated at $3{ }^{\circ} \mathrm{C}$ and $6{ }^{\circ} \mathrm{C}$ significantly differed $(\mathrm{P}<0.05)$ at most time points; however, at $9{ }^{\circ} \mathrm{C}$, a difference $(\mathrm{P}<0.05)$ only occurred between T-2 and T-3 at the time of collection (time zero). For Groups 1 and 2, the T-4 (no preservative) samples statistically differed $(\mathrm{P}<0.05)$ the most from those of the other treatments at all three temperatures tested.

Regarding within preservative treatments, there was no association between the variables $(\mathrm{P}>0.05)$ in Group 1, whereas in Group 2, as incubation time increased, the bacterial count decreased. This inverse relationship indicated an association between variables $(\mathrm{P} \leq 0.05)$. There was also an association between the variables for the T- 4 treatment of both milk groups (G-1 and G-2).

Based on the results for the T- 4 treatment, with a progressive increase in incubation time causing a consequent deterioration in the samples, the time required between collection and analysis justifies the need to use a preservative in association with refrigeration. Figure 1 shows the effects of storage time over the 14-day period on the four treatments at $3{ }^{\circ} \mathrm{C}, 6$ ${ }^{\circ} \mathrm{C}$ and $9{ }^{\circ} \mathrm{C}$. Graphs A, B and $\mathrm{C}$ show the results for the G-1 milk group, while Graphs D, E, F are those for G-2.

Microorganisms can double their populations every 20 to 30 minutes (GUERREIRO et al., 2005), with the rate of multiplication related primarily to the initial contamination in the milk (RECHE et al., 2015). ZENI (2014) notes that a low initial bacterial load combined with low-temperature storage is best for maintaining milk's microbiological quality, stressing the importance of temperature, as the storage time influences the bacterial count.

The use of bacteriostatic preservatives reduces the metabolic activity of bacteria, providing greater longevity for samples (CASSOLI et al., 2007). MARTINS et al. (2009) argued that the bacteriostatic effect of azidiol is influenced by the temperature at which the raw milk samples are stored, meaning the efficiency of this preservative depends on storage temperature. However, ALMEIDA et al. (2016) and SOUZA et al. (2006) observed no differences between samples stored at temperatures from $3{ }^{\circ} \mathrm{C}$ to $11{ }^{\circ} \mathrm{C}$ and from $3.8^{\circ} \mathrm{C}$ to $10^{\circ} \mathrm{C}$, respectively. In addition, ELIZONDO et al. (2005) used preservative efficacy tests to evaluate different doses of liquid azidiol for sample preservation and reported no difference between the usual concentration used and a half dose of the preservative.

CASSOLI et al. (2010) and CASSOLI et al. (2007) reported that bacterial counts were not affected until Day 7, with samples remaining analytically viable when the storage temperature was $7^{\circ} \mathrm{C}$. Similar findings were obtained by SOUZA et al. (2006) at temperatures between $3.8^{\circ} \mathrm{C}$ and $10^{\circ} \mathrm{C}$ and by ZENI (2014) at $10^{\circ} \mathrm{C}$. However, SESKENA \& JANKEVICA (2007), GONZALO et al. (2003), and NINANE et al. (2000) have suggested that samples could be analyzed only until the 4 th day after collection when refrigerated at $4{ }^{\circ} \mathrm{C}$. In contrast, MARTINS et al. (2009), and ALMEIDA et al. (2016) have advocated for preserving samples for up to 10 days at $4{ }^{\circ} \mathrm{C}, 4{ }^{\circ} \mathrm{C}$ to $10^{\circ} \mathrm{C}$, and $17{ }^{\circ} \mathrm{C}$, respectively. ALMEIDA et al. (2016) also 


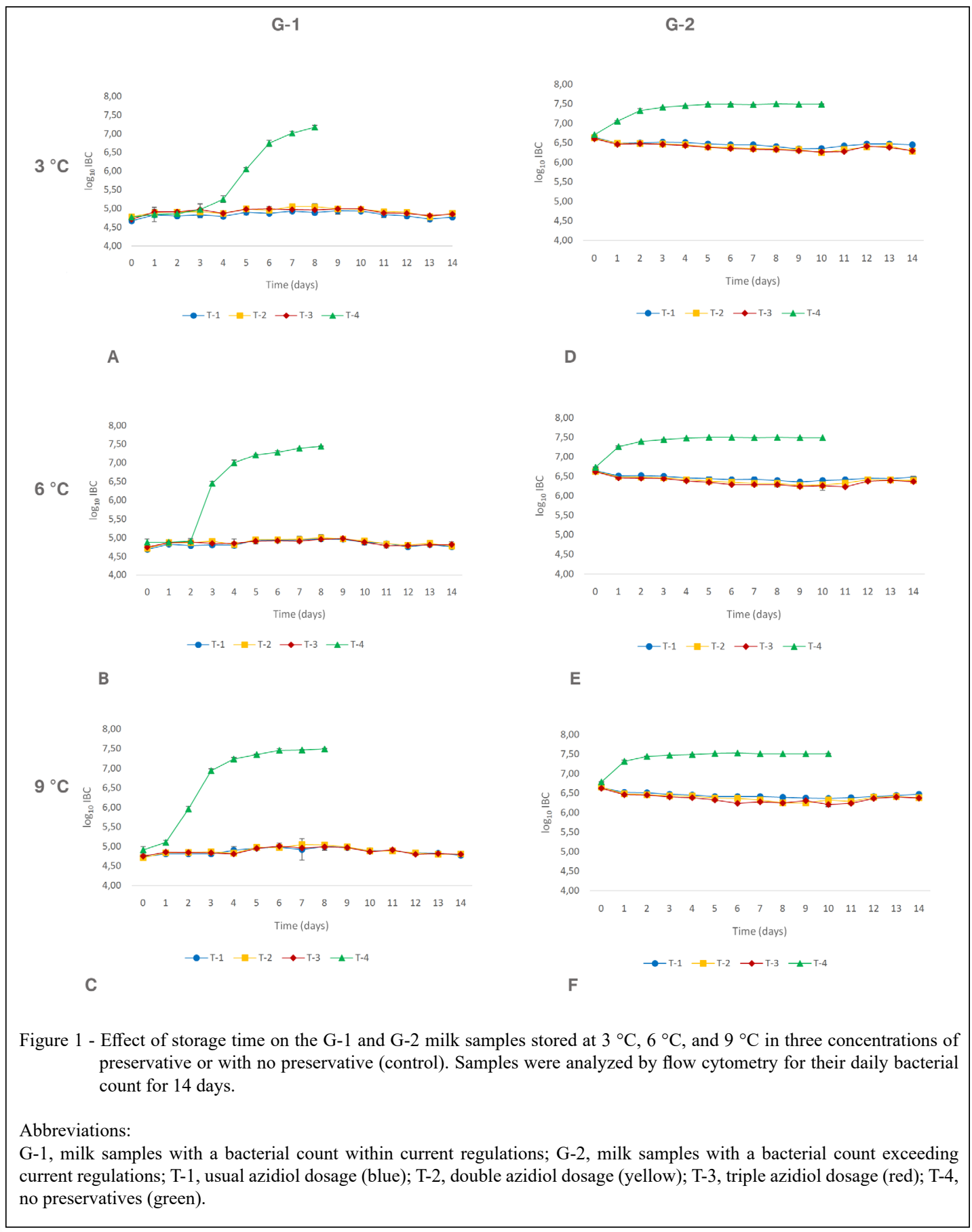

proposed that samples could be preserved for up to 16 days when stored at $11^{\circ} \mathrm{C}$.

WENTZ et al. (2018) have shown that for samples containing azidiol, there is a reduction in the bacterial count over time, regardless of storage temperature. However, SAMPAIO et al. (2015) and ROSA (2012) mention that depending on the number and type of microorganisms, as well as the incubation time, there can be undesirable changes in the appearance and/or smell of the milk. The presence of gas is also possible, which can be indicative of coliform, aerobic, or facultative anaerobic bacteria that ferment lactose to produce acid and gas, leading to deterioration.

\section{CONCLUSION}

The tripled concentrations of sodium azide and chloramphenicol provided the best conditions for

Ciência Rural, v.50, n.2, 2020. 
preserving milk samples. This concentration was the superior alternative for extending the analytical shelf life of the samples, as it allowed for accurate bacterial counts for up to 12 days when stored at $3{ }^{\circ} \mathrm{C}$ and for up to the 8 days when maintained at $6{ }^{\circ} \mathrm{C}$.

\section{ACKNOWLEDGEMENTS}

We thank the State Laboratory of Milk Quality LabLeite of the University of Contestado - UnC for granting the structure for the research.

\section{DECLARATION OF CONFLICT OF INTERESTS}

The authors declare no conflict of interest. The founding sponsors had no role in the design of the study; in the collection, analyses, or interpretation of data; in the writing of the manuscript, and in the decision to publish the results.

\section{AUTHORS' CONTRIBUTIONS}

The authors contributed equally to the manuscript.

\section{REFERENCES}

ALMEIDA, T. V. et al. Effect of temperature and time of storage of raw milk samples on electronic analysis results. (Arquivo Brasileiro de Medicina Veterinária e Zootecnia), v.68, n.5, p.1316-1324, 2016. Available from: <http://dx.doi.org/10.1590/1678-41628957>. Accessed: Jan. 2018. doi: 10.1590/1678-4162-8957.

BENTLEY INSTRUMENTS INC. BactoCount 150 Operator's Manual. Chaska: Bentley Instruments Inc., 2002.

BRASIL. Ministry of Agriculture, Livestock and Food Supply (Ministério da Agricultura, Pecuária e Abastecimento). Normative Instruction No. 76 from 11/26/2018 (Instrução Normativa $N^{\circ} 76$ de 26/11/2018). Approves the Technical Regulations Establishing the Identity and Quality Characteristics of Refrigerated Raw Milk, Pasteurized Milk and Type A Pasteurized Milk. Official Union Journal (Diário Oficial da União). Brasilia/DF, Nov 26th, 2018.

BRASIL. Ministry of Agriculture, Livestock and Food Supply (Ministério da Agricultura, Pecuária e Abastecimento). Normative Instruction No. 51 of 18/09/2002 (Instrução Normativa $\mathbf{N}^{\circ}$ 51 de 18/09/2002). Approves the Technical Regulations for the Production, Identity and Quality of Type A Milk, Type B Milk, Type C Milk, Pasteurized Milk, and Refrigerated Raw Milk and the Technical Regulations for the Collection of Refrigerated Raw Milk and Its Bulk Transport. Official Union Journal (Diário Oficial da União). Brasília/DF, September 20, 2002.

CASSOLI, L. D. et al. Correlation study between standard plate count and flow cytometry for determination of raw milk total bacterial count. International Journal of Dairy Technology, v.60, n.1, p.44-48, 2007. Available from: <https://onlinelibrary.wiley. com/doi/abs/10.1111/j.1471-0307.2007.00297.x>. Accessed: Jan. 2018. doi: 10.1111/j.1471-0307.2007.00297.x.

CASSOLI,L.D. et al. Milk sample conservation methods to determine the total bacteria count by flow cytometry (Métodos de conservação de amostras de leite para determinação da contagem bacteriana total por citometria de fluxo). Revista Brasileira de Zootecnia, 1659 v.39, n.2, p.434-439, 2010. Available from: <http://www.scielo.br/ scielo.php?script=sci_arttext\&pid=S1516-35982010000200029>. Accessed: Jan. 2018. doi: 10.1590/S1516-35982010000200029.

ELIZONDO, J. et al. Efficiency of the proportion of azide on preservation in ewes' milk samples for analysis. Food Control, v.18, p.185-190, 2005. Available from: <http://dx.doi. org/10.1016/j.foodcont.2005.09.011>. Accessed: Jan. 18, 2018. doi: 10.1016/j.foodcont.2005.09.011.

GONZALO, C. et al. Fossomatic cell-counting on ewe milk: comparison with direct microscopy and study of variation factor. Journal of Dairy Science, v.86, p.138-145, 2003. Available from: <https://www.journalofdairyscience.org/article/S00220302(03)73593-0/fulltext>. Accessed: Jan. 18, 2018. doi: 10.3168/jds.S0022-0302(03)73593-0.

GUERREIRO, P. K. et al. Microbiological quality of milk through preventative techniques in the handling of production (Qualidade microbiológica de leite em função de técnicas profiláticas no manejo de produção). (Ciência e Agrotecnologia), v.29, n.1, p.216-222, 2005. Available from: <http://dx.doi.org/10.1590/ S1413-70542005000100027>. Accessed: Jan. 18, 2018. doi: 10.1590/S1413-70542005000100027.

INTERNATIONAL DAIRY FEDERATION. Milk: Quantitative determination of bacteriological quality - Guidance for establishing and verifying a conversion relationship between routine method results and anchor method results. IDF Standard, n. 196. Brussels: International Dairy Federation, 2004.

MARTINS, M. E. P. et al. Bronopol and azidiol chemicals: time and temperature influence in the total bacterial count of raw milk. Brazilian Animal Science (Ciência Animal Brasileira), v.10, n.2, p.627-633, 2009. Available from: <https://www.revistas.ufg.br/ vet/article/view/3913>. Accessed: Jan. 23, 2018.

NINANE, V. et al. Evaluation of Bactoscan FC for the enumeration of raw milk bacteria (Évaluation du Bactoscan FC pour la numeration des bactéries du lait cru). Le Lait, v.80, p.527-538, 2000. Available from: <https://lait.dairy-journal.org/articles/lait/ abs/2000/05/L0506/L0506.html>. Accessed: Jan. 25, 2018. doi: 10.1051/lait:2000143.

RECHE, N. L. M. et al. Microbial multiplication in raw milk stored in direct expansion bulk tanks. Rural Science (Ciência Rural), v.45, n.5, p.828-834, 2015. Available from: $<$ http://dx.doi. org/101590/0103-8478cr20140542>. Accessed: Jan. 25, 2018. doi: $101590 / 0103-8478 \mathrm{cr} 20140542$.

ROSA, D.C. et al. Milk quality in samples from individual dairy cows and milk tanks. Arquivos do Instituto Biológico, v.79, n.4, p.485-493, 2012. Available from: <https://www.researchgate. net/publication/260771945 Milk quality in samples from individual_dairy_cows_and_milk_tanks $>$. Accessed: Jan. 25, 2018. doi: $10.1590 / \mathrm{s} 1808-16572012000400004$.

SAMPAIO V. S. C. et al. Influence of different types of microorganisms on total bacterial count by flow cytometry of refrigerated raw milk (Influência de diferentes tipos de microorganismos na contagem bacteriana total por citometria de fluxo do leite cru refrigerado). Brazilian Archive of Veterinary Medicine and Animal Science (Arquivo Brasileiro de Medicina Veterinária e Zootecnia), v.67, n.2, p.607-612, 2015. Available 
from: <http://dx.doi.org/10.1590/1678-7257>. Accessed: Jan. 25, 2018. doi: $10.1590 / 1678-7257$.

SESKENA, R.; JANKEVICA, L. Influence of chemical preservatives on the quality and composition indices of raw milk. Acta Universitatis Lativiensis, v.723, p.171-180, 2007. Available from: <http://eeb.lu.lv/ EEB/2007/Seskena.pdf>. Accessed: Jan. 25, 2018.

SOUZA, G. N. et al. Effect of temperature and storage time on counting total bacteria in azidiol-preserved raw milk samples (Efeito da temperatura e do tempo de armazenamento sobre a contagem total de bactérias em amostras de leite cru conservadas com azidiol). Journal of Cândido Tostes Dairy Institute (Revista do Instituto de Laticínios Cândido Tostes), v.61, 2006. Available from: $\quad<$ http://www.scielo.br/scielo.php?script=sci arttext\&pid =S0102-09352016000501316>. Accessed: Jan. 25, 2018. doi: $10.1590 / 1678-4162-8957$.
TRONCO, V. M. Manual for milk quality inspection (Manual para inspeção de qualidade do leite). Santa Maria/RS: Ed. UFSM, 2010.

WENTZ, A. G. et al. Different methods and times of milk conservation: physical-chemical composition and microbiological quality. Acta Veterinária Brasileira, v.12, n.3, p.84-93, 2018. Available from: <https://periodicos.ufersa.edu.br/index.php/ acta/article/view/7698>. Accessed: Jan. 25, 2018. doi: 10.21708/ avb.2018.12.3.7698.

ZENI, E. Effect of the binomial time and temperature of conservation on the hygienic-sanitary quality aspect of goat's milk (Efeito do binômio tempo e temperatura de conservação sobre o aspecto de qualidade higiênico-sanitário do leite de cabra). Dissertation (Master's degree in Science and Technology of Dairy Products), Federal University of Juíz de Fora, Juíz de Fora/MG, 2014. 